\title{
Soil Tillage Systems and Wheat Yield under Climate Change Scenarios
}

\author{
Pieranna Servadio ${ }^{1, *}$, Simone Bergonzoli ${ }^{1}$ and Claudio Beni ${ }^{2}$ \\ 1 Council for Agricultural Research and Economics, Agricultural Engineering Research Unit (CREA-ING), \\ 00016 Monterotondo, Rome, Italy; simone.bergonzoli@crea.gov.it \\ 2 Council for Agricultural Research and Economics, Research Centre for Soil-Plant System (CREA-RPS), \\ 00184 Rome, Italy; claudio.beni@crea.gov.it \\ * Correspondence: pieranna.servadio@crea.gov.it; Tel.: +39-06-9067-5223
}

Academic Editors: Yantai Gan, Paul C. Struik and Peter Langridge

Received: 31 March 2016; Accepted: 13 September 2016; Published: 20 September 2016

\begin{abstract}
In this study, the effects of three different main preparatory tillage operations: ploughing at $0.4 \mathrm{~m}$ (P40) and $0.20 \mathrm{~m}$ (P20) depth and harrowing at $0.20 \mathrm{~m}$ depth (MT) were investigated. The tillage operations were carried out at two different times, as the soil water content increased over time from rainfall: (low, 58\% (LH) and high, $80 \%(\mathrm{HH})$ of field capacity). Results obtained from the soil monitoring carried out before and after tillage showed high values of soil strength in terms of Penetration resistance and shear strength particularly in deeper soil layers at lower water content. During tillage, fossil-fuel energy requirements for P40 LH and P20 LH were $25 \%$ and $35 \%$ higher, respectively, with respect to the $\mathrm{HH}$ treatments and tractor slip was very high ( $\mathrm{P} 40 \mathrm{LH}=32.4 \%)$ with respect to the $\mathrm{P} 40 \mathrm{HH}$ treatment $(16 \%)$. Soil water content significantly influenced tractor performance during soil ploughing at $0.40 \mathrm{~m}$ depth but no effect was observed for the MT treatment. The highly significant linear relations between grain yield and soil penetration resistance highlight how soil strength may be good indicator of soil productivity. We conclude that ploughing soil to a $0.20 \mathrm{~m}$ depth or harrowing soil to a $0.20 \mathrm{~m}$ depth is suitable for this type of soil under climate change scenarios.
\end{abstract}

Keywords: soil tillage; tractors; soil water content; physical soil properties; GPS; energy requirement; $\mathrm{CO}_{2}$ emission

\section{Introduction}

The number of days available for field operations is central to farm planning decisions. The number and distribution of working days influences the type and acreage of crops grown, and the corresponding labour and machinery requirements. The condition of land for field operations can be classified in terms of trafficability and workability. Trafficability is concerned with the ability of soil to provide adequate traction for vehicles, and withstand traffic without excess compaction or structural damage. If land is considered trafficable, then it is deemed suitable for non-soil-engaging operations (e.g., fertilizer application and crop protection). Workability is concerned with soil-engaging operations and can be considered to be a combination of trafficability and the ability of soil to be manipulated in a desired way without causing significant damage or compaction. The most influential factor in determining the suitability of land for field operations is the soil moisture status. When a soil is trafficked or worked in an unsuitable condition, damage to the soil's structure and the consequent effect on crop production can persist for many years [1]. In mechanised agriculture, high axle loads are the cause of major concern regarding the risk of soil compaction, especially if wheeling and tillage are conducted at high soil moisture content [2,3]. Tillage is a fundamental factor influencing soil quality, 
crop performance and the sustainability of cropping systems [4] because tillage can alter soil physical properties, the depth of soil profile, and the management of crop residues applied to the soil.

Soil penetration resistance measurements have been used in many studies as a tool for characterizing soil strength after tillage $[5,6]$. However, soil penetration resistance and other soil properties are often affected by soil spatial variability [7] and are strongly dependent on soil water content [8-10]. Therefore, the spatial and temporal variability of soil compaction is related to soil moisture. Soil moisture content during tillage affects the size distribution of aggregates and those aggregates formed at low moisture content have three to four times more resistance to crushing than those formed at greater moisture contents [11]. The type of tillage implement also affects the soil structure. Tillage implements vary in terms of width and depth and intensity in soil are affected by the implement design (disc versus ploughing, etc.). Furthermore, interactions between natural factors (e.g., soil type, climate and weather) and crop selection determine the intensity, depth, frequency, and timing of tillage [12]. There is a need for understanding the tillage effects on soil properties, tractor performance and crop yield [13,14]. Tillage systems are location specific, so the degree of their success depends on soil, climate, and management practices $[15,16]$.

In recent years, the weather conditions in Central Italy have been unstable. In summer, soil is very dry, and in autumn and in spring time, soil is very wet. Rainfall is generally delayed until November-December. Hence, farmers face difficulties in accomplishing the seedbed preparation at the proper time. As a result, the drilling of cereals such as wheat and barley is usually delayed, which decreases crop yield. Therefore, the objectives of this study were to assess which tillage techniques could be considered as adaptation to climate change scenarios (CCS). For this, the effects of three different main preparatory tillage operations: ploughing to $0.4 \mathrm{~m}$ and $0.2 \mathrm{~m}$ depth and harrowing to $0.2 \mathrm{~m}$ depth were compared and their effect on crop performance was quantified. Each of the tillage systems was tested at two different times, with the soil water content was low at $58 \%$ (LH) and high at $80 \%(\mathrm{HH})$ of field capacity. The effect of the different tillage operations was assessed through wheat yield, clod size, soil water infiltration, structural stability, cone index and shear strength.

\section{Materials and Methods}

The study was conducted in Central Italy on a hilly plateau (57 $\mathrm{m}$ a.s.1.), ( $42^{\circ} 05^{\prime} 57.84^{\prime \prime} \mathrm{N}$, $12^{\circ} 38^{\prime} 09.59^{\prime \prime}$ E) on a silt loam soil. Three tillage systems: harrowing $0.20 \mathrm{~m}$ depth coded MT; ploughing, superficial ( $0.2 \mathrm{~m}$ depth) coded P20 and deeper ( $0.4 \mathrm{~m}$ depth) coded P40, were compared. All treatments were carried out at two different times (21 October and 15 November 2010), as the soil water content increased over time from rainfall as shown in Figure 1: low humidity $(18 \%$, treatments $\mathrm{LH})$, corresponding to $58 \%$ of field capacity and high humidity ( $25 \%$, treatments $\mathrm{HH})$, corresponding to $80 \%$ of field capacity (Table 1 ).

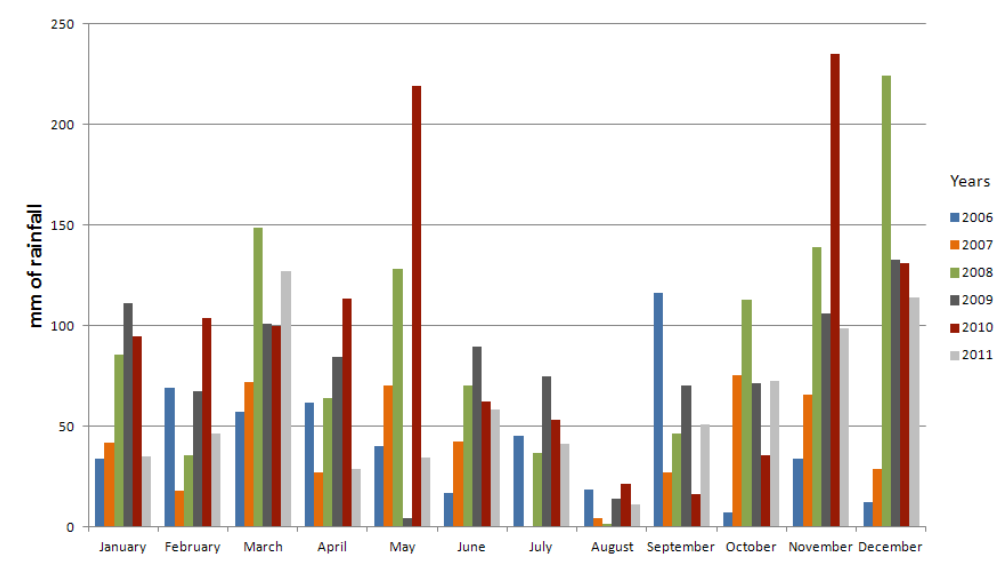

Figure 1. Monthly rainfall data of the experimental site during the tests (2010-2011). Data since 2006 indicate the climatic average. 
Table 1. Soil conditions during field tests (0-0.20 $\mathrm{m}$ depth).

\begin{tabular}{lcc}
\hline & Sand $(2000-50 \mathrm{~mm})$ & 24.7 \\
Particle size distribution (\%): & Silt $(50-2 \mathrm{~mm})$ & 52.5 \\
& Clay $(<2 \mathrm{~mm})$ & 22.7 \\
\hline Texture & Silty loam \\
$\mathrm{pH}$ & 6.4 \\
Organic matter (\%) & 2.4 \\
Field capacity (\%) & 31 \\
\hline Moisture content $(\%)$ measured during: & \\
Soil sampling tests carried out on 20 October 2010 & & \\
Soil tillage carried out on 21 October 2010 & (LH) \\
Soil tillage carried out on 15 November 2010 & $(\mathrm{HH})$ & 25 \\
Soil sampling tests carried out on 15 February 2011 & & 22 \\
\hline
\end{tabular}

The main factor was the soil tillage (MT, P20 and P40) while the secondary factor was the soil water content (LH and HH). The treatments coded: P40 LH, P40 HH, P20 LH, P20 HH, MT LH, MT $\mathrm{HH}$ were arranged according to a split plot design (six treatments per three replications) for a total of eighteen plots each of $200 \mathrm{~m}^{2}$, in three blocks. After the ploughing, no additional seedbed preparation was necessary because the meteorological events favoured clod disaggregation. All plots were seeded (28 November 2010) with wheat (Triticum durum variety Duilio $0.21 \mathrm{t} \cdot \mathrm{ha}^{-1}$ ). Plots were fertilized with: (1) NP (11-30) fertilizer (0.1 t.ha ${ }^{-1}$ ) the day before the sowing time; (2) urea 46\% on 27 February 2011 $\left(0.1 \mathrm{t} \cdot \mathrm{ha}^{-1}\right)$; (3) urea $46 \%$ on 9 April $2011\left(0.1 \mathrm{t} \cdot \mathrm{ha}^{-1}\right)$. Harvesting of wheat was carried out on 30 June 2011. At the end, relations between measured soil strength and wheat yield were developed.

\subsection{Soil Sampling Tests}

To assess soil mechanical conditions, the soil properties water content (WC), penetration resistance (CI) and shear strength (SS) were monitored at two different times. One georeferenced sampling test was conducted before starting the trials (20 October 2010) and another after the tillage (15 February 2011), as shown in Table 1. Penetration resistance was measured using an Eijkelkamp penetrologger with a $60^{\circ}$ cone and base area of $100 \mathrm{~mm}^{2}$, driven into the soil at a constant rate $\left(5 \mathrm{~cm} \cdot \mathrm{s}^{-1}\right)$. In each plot, 4 penetrometer readings were taken at increments of $1 \mathrm{~cm}$ to a depth of $0.40 \mathrm{~m}$. Soil shear strength was measured using a field inspection vane tester from 0 to $260 \mathrm{kPa}$ (Eijkelkamp Agrisearch Equipment, Giesbeek, The Netherlands). In each plot, 6 shear strength readings were taken at increments of $0.05 \mathrm{~m}$ to a depth of $0.20 \mathrm{~m}$. Soil water content at the time of field tests was measured from 0 to $0.20 \mathrm{~m}$ depth by taking 6 samples of soil in each plot that were weighed and dried until they reached a constant weight. The Richards water extraction apparatus was used to determine soil field capacity (FC).

\subsection{Soil Tillage}

To assess which tillage techniques could be considered as adaptation to climate change scenarios (CCS) in central Italy, soil tillage was carried out at two different times: in October at low water content ( $58 \%$ FC) and in November at high water content ( $80 \%$ FC). Some field conditions during the tests are shown in Table 1 while Figure 1 shows monthly rainfall data of the experimental site from 2006-2011. Due to the work width and mass of the trailed disk harrow, harrowing was carried out using a mean power metal tracked tractor (62 kW engine power, $4100 \mathrm{~kg}$ mass front ballasted) while ploughing with a mounted furrow plow was carried out using a mean power wheeled tractor (62 $\mathrm{kW}$ engine power, $3400 \mathrm{~kg}$ mass front ballasted). The performance of tractors carrying out tillage operations was evaluated through: forward speed, slip, global energy employed, effective work capacity, real work width and work depth, fossil-fuel energy requirements (GJ/ha) and carbon dioxide emissions (kg.C/ha). In addition, field data collected allow the appraisal of the global energetic efficiency of the tractors that depends on the area (ha) covered as a function of the time and from the ability of 
the tractor to convert the energy of combustion into useful power. As a result, three field-oriented performance indicators based on time efficiency (h/ha), area specific consumption $\left(\mathrm{kg}^{\mathrm{h}} \mathrm{ha}^{-1}\right)$ and slip $(\%)$ were applied $[16,17]$.

In order to evaluate the quality of the tillage operations, the followings parameters were measured by collecting 6 samples per plot: clod size distribution, water infiltration rate into the soil, structural stability of soil aggregates. Clod size distribution was determined by taking samples of tilled soil, sifting them through sieves with holes of 200,100, 50, 25 and $10 \mathrm{~mm}$ in diameter and then separating them into size classes $[13,14]$. The structural stability of soil aggregates in the $0.25 \mathrm{~mm}$ fraction was determined through the method of [18]; the water infiltration rate was measured using a double ring infiltrometer [19], according to the Simplified Falling Head (SFH) technique suggested by [20] with a $32 \mathrm{~cm}$ inner diameter and $57 \mathrm{~cm}$ outer diameter cylinder inserted $5 \mathrm{~cm}$ into the soil. The wheat harvesting was carried out by hand in the sampling areas consisting in $1 \mathrm{~m}^{2}$ (6 replications); the sampling areas were chosen through a subjective method suggested by [21].

\subsection{Statistical Methods}

Statistically significant differences between treatments were determined by means of the Student's test and were performed at the same depth of the samples for the soil variables. Mean results are flanked on the same line by letters. Each mean, that shares a letter does not differ significantly; level of significance: $\leq 0.01$ [22].

\section{Results}

\subsection{Soil Sampling Tests}

Due to the low water content ( $58 \% \mathrm{FC})$, soil was very strong during the sampling tests carried out before tillage on 20 October 2010. In fact, as shown in Tables 2 and 3, the values of penetration resistance ( $\mathrm{CI}$ in the deeper layer up to $4 \mathrm{MPa}$ ) and of shear strength (SS up to $189 \mathrm{kPa}$ ) were highly elevated. Because of the effect of soil tillage and the higher water content $(80 \% \mathrm{FC})$, these values decreased significantly $(\Delta>50 \%)$ in the sampling tests carried out after tillage on 15 February 2011.

Table 2. Mean values of soil layers from 0 to $0.40 \mathrm{~m}$, depth of penetration resistance carried out before (B) and after (A) tillage and its increment ratio $\Delta$.

\begin{tabular}{ccccc}
\hline Treatments & Depth (m) & $\begin{array}{c}\text { Mean Penetration Resistance * } \\
\text { (MPa) (20 October 2010) (B) }\end{array}$ & $\begin{array}{c}\text { Mean Penetration Resistance * } \\
\text { (MPa) (15 February 2011) (A) }\end{array}$ & $\Delta=\frac{B-A}{B}$ \\
\hline \multirow{2}{*}{ MT LH } & $0.0-0.20$ & $2.77^{\mathrm{a}}$ & $1.34^{\mathrm{b}}$ & 0.52 \\
& $0.21-0.40$ & $4.36^{\mathrm{b}}$ & $1.91^{\mathrm{a}}$ & 0.56 \\
\hline \multirow{2}{*}{ P20 LH } & $0.0-0.20$ & $2.53^{\mathrm{c}}$ & $0.91^{\mathrm{e}}$ & 0.64 \\
& $0.21-0.40$ & $3.99^{\mathrm{e}}$ & $1.55^{\mathrm{f}}$ & 0.61 \\
\hline \multirow{2}{*}{ P40 LH } & $0.0-0.20$ & $2.19^{\mathrm{d}}$ & $0.92^{\mathrm{e}}$ & 0.58 \\
& $0.21-0.40$ & $3.89^{\mathrm{e}}$ & $1.30^{\mathrm{f}}$ & 0.66 \\
\hline \multirow{2}{*}{ MT HH } & $0.0-0.20$ & $2.48^{\mathrm{a}}$ & $1.32^{\mathrm{b}}$ & 0.47 \\
& $0.21-0.40$ & $4.41^{\mathrm{b}}$ & $1.91^{\mathrm{a}}$ & 0.57 \\
\hline \multirow{2}{*}{ P20 HH } & $0.0-0.20$ & $2.42^{\mathrm{ac}}$ & $1.26^{\mathrm{a}}$ & 0.48 \\
\hline \multirow{2}{*}{ P40 HH } & $0.21-0.40$ & $3.75^{\mathrm{d}}$ & $1.83^{\mathrm{b}}$ & 0.51 \\
\hline
\end{tabular}

${ }^{*}$ Average of 240 values. Each mean, that shares a letter does not differ significantly; level of significance: $\leq 0.01$. 
Table 3. Mean values from 0 to $0.20 \mathrm{~m}$ depth for shear strength carried out before (B) and after (A) tillage and its increment ratio $\Delta$.

\begin{tabular}{|c|c|c|c|c|}
\hline Treatments & Depth (m) & $\begin{array}{l}\text { Mean Shear Strength * }(\mathrm{kPa}) \\
(20 \text { October 2010) }(\mathrm{B})\end{array}$ & $\begin{array}{c}\text { Mean Shear Strength * }(\mathrm{kPa})(15 \\
\text { February 2011) (A) }\end{array}$ & $\Delta=\frac{B-A}{B}$ \\
\hline MT LH & $0.0-0.20$ & $172.83^{\mathrm{a}, \mathrm{b}}$ & $83.83^{\mathrm{a}}$ & 0.51 \\
\hline P20 LH & $0.0-0.20$ & $155.67^{\mathrm{a}}$ & $42.33^{\mathrm{b}}$ & 0.72 \\
\hline P40 LH & $0.0-0.20$ & $188.67^{\mathrm{b}}$ & $56.50^{\mathrm{b}, \mathrm{c}}$ & 0.70 \\
\hline MT HH & $0.0-0.20$ & $154.50^{\mathrm{a}}$ & $72.75^{a, b}$ & 0.52 \\
\hline P20 HH & $0.0-0.20$ & $165.33^{\mathrm{a}}$ & $45.42^{b}$ & 0.72 \\
\hline P40 H & $0.0-0.20$ & $177.50^{\mathrm{a}}$ & $37.67^{\mathrm{b}}$ & 0.78 \\
\hline
\end{tabular}

* Average of 72 values. Each mean, that shares a letter does not differ significantly; level of significance: $\leq 0.01$.

\subsection{Soil Tillage}

Due to the high soil strength in terms of CI and SS obtained in the tests carried out at low water content, the tractor performance during ploughing was not that good if compared with other studies, for instance, in a silty clay soil (water content at 0.25 of the field capacity) with $217 \mathrm{~kW}$ powered wheeled tractor [16]. In fact, the three field-oriented performance indicators of time efficiency (h/ha), area specific consumption $\left(\mathrm{kg} \cdot \mathrm{ha}^{-1}\right)$ and slip (\%) applied showed:

(1) in the tests carried out at low water content LH (58\% FC), the results of the time efficiency were very low ( 8 and $6.3 \mathrm{~h} \cdot \mathrm{ha}^{-1}$ ) for 0.40 and $0.20 \mathrm{~m}$, respectively (Table 4 ). Accordingly, the respective results of area-specific consumption for 0.40 and $0.20 \mathrm{~m}$ were 120 and $91 \mathrm{~kg} \cdot \mathrm{ha}^{-1}$, and the fossil-fuel energy requirements were 4.67 and $3.54 \mathrm{GJ} \cdot \mathrm{ha}^{-1}$ ) and the $\mathrm{CO}_{2}$ emission were 101 and $77 \mathrm{~kg} \cdot \mathrm{C} \cdot \mathrm{ha}^{-1}$ ), which were very high. Besides, the tractor slip was very high (32.4\%), particularly for ploughing at the $0.40 \mathrm{~m}$ depth.

(2) in the tests carried out in November 2010 at higher water content $\mathrm{HH}(80 \%$ FC, $)$, with an increase in rainfall over time, as Figure 1 shows, the results were significantly better: the time efficiencies were 6 and $4 \mathrm{~h} \cdot \mathrm{ha}^{-1}$ for 0.40 and $0.20 \mathrm{~m}$, respectively (Table 5). Accordingly, the respective results for the 0.40 and $0.20 \mathrm{~m}$ depths were: area specific consumption of 91 and $60 \mathrm{~kg} \cdot \mathrm{ha}^{-1}$, fossil-fuel energy requirements of 3.54 and $2.33 \mathrm{GJ} \cdot \mathrm{ha}^{-1}$ and $\mathrm{CO}_{2}$ emission of 77 and $51 \mathrm{~kg} \cdot \mathrm{C} \cdot \mathrm{ha}^{-1}$. Tractor slip (16\% and 17\%) can be considered as good for a wheeled tractor during ploughing. Tractor slip is an index of traction performance and to obtain the maximum traction efficiency, the slip must range from $15 \%$ to $20 \%$ on dry soil and from $15 \%$ to $25 \%$ on wet soil [9].

(3) Between the two different field conditions (low and high water content), the performance of the tracked tractor during harrowing was of the same magnitude for the MT treatment: the time efficiency was $1.2 \mathrm{~h} \cdot \mathrm{ha}^{-1}$. Accordingly, the results of area-specific consumption was $15 \mathrm{~kg} \cdot \mathrm{ha}^{-1}$, the fossil-fuel energy requirement was $0.58 \mathrm{GJ} \cdot \mathrm{ha}^{-1}$ and $\mathrm{CO}_{2}$ emission was $13 \mathrm{~kg} \cdot \mathrm{C} \cdot \mathrm{ha}^{-1}$.

Table 4. Performance of tracked and wheeled tractors during soil tillage carried out at low soil water content low humidity (LH) (58\% FC).

\begin{tabular}{cccc}
\hline Performance & P40 LH & P20 LH & MT LH \\
\hline Forward speed $\left(\mathrm{m} \cdot \mathrm{s}^{-1}\right)$ & 0.73 & 0.93 & 0.93 \\
Measured work width $(\mathrm{m})$ & 0.5 & 0.5 & 2.5 \\
Effective work capacity $\left(\mathrm{ha} \cdot \mathrm{h}^{-1}\right)$ & 0.13 & 0.17 & 0.84 \\
Time efficiency $\left(\mathrm{h} \cdot \mathrm{ha}^{-1}\right)$ & 8.09 & 6.28 & 1.19 \\
Slip $(\%)$ & 32.4 & 14.3 & 5.0 \\
Hourly fuel consumption $\left(\mathrm{kg} \cdot \mathrm{h}^{-1}\right)$ & 15 & 14.5 & 12.5 \\
Area-specific consumption $\left(\mathrm{kg} \cdot \mathrm{ha}^{-1}\right)$ & 120 & 91 & 15 \\
Global energy employed $\left(\mathrm{kWh} \cdot \mathrm{ha}^{-1}\right)$ & 310 & 235 & 183 \\
Energy $\left(\mathrm{GJ} \cdot \mathrm{ha}^{-1}\right)$ & 4.67 & 3.54 & 0.58 \\
$\mathrm{CO}_{2}$ emission $\left(\mathrm{kg} \cdot \mathrm{C} \cdot \mathrm{ha}^{-1}\right)$ & 101 & 77 & 13 \\
\hline
\end{tabular}


Table 5. Performance of tracked and wheeled tractors during soil tillage carried out at high soil water content $\mathrm{HH}(80 \% \mathrm{FC})$.

\begin{tabular}{cccc}
\hline Performance & P40 HH & P20 HH & MT HH \\
\hline Forward speed $\left(\mathrm{m} \cdot \mathrm{s}^{-1}\right)$ & 0.90 & 1.34 & 0.94 \\
Measured work width $(\mathrm{m})$ & 0.5 & 0.5 & 2.5 \\
Effective work capacity $\left(\mathrm{ha} \cdot \mathrm{h}^{-1}\right)$ & 0.16 & 0.24 & 0.85 \\
Time efficiency $\left(\mathrm{h} \cdot \mathrm{ha}^{-1}\right)$ & 6.25 & 4.17 & 1.18 \\
Slip $(\%)$ & 15.8 & 17.0 & 5.1 \\
Hourly fuel consumption $\left(\mathrm{kg} \cdot \mathrm{h}^{-1}\right)$ & 14.5 & 14.5 & 12.5 \\
Area-specific consumption $\left(\mathrm{kg} \cdot \mathrm{ha}^{-1}\right)$ & 91 & 60 & 15 \\
Global energy employed $\left(\mathrm{kWh} \cdot \mathrm{ha}^{-1}\right)$ & 250 & 166 & 182 \\
Energy $\left(\mathrm{GJ} \cdot \mathrm{ha}^{-1}\right)$ & 3.54 & 2.33 & 0.58 \\
$\mathrm{CO}_{2}$ emission $\left(\mathrm{kg} \cdot \mathrm{C} \cdot \mathrm{ha}^{-1}\right)$ & 77 & 51 & 13 \\
\hline
\end{tabular}

Because it influences the quality of the tillage, the clod size distribution showed a good quality, especially for the treatments $\mathrm{P} 20 \mathrm{HH}$ and $\mathrm{MT} \mathrm{HH}$, where a high percentage of clods less than $50 \mathrm{~mm}$ and the absence of clods greater than $200 \mathrm{~mm}$ were found (Figure $2 \mathrm{~b}$ ). The others treatments showed: (i) higher percentage of clods larger than $200 \mathrm{~mm}(50 \%)$ for P40 HH and (30\%) for P40 LH; (ii) almost the same trend under the $\mathrm{LH}$ and $\mathrm{HH}$ conditions for the MT treatments and (iii) opposite trend under the LH and HH conditions for P20 treatments where LH had more than $40 \%$ of clods larger than $200 \mathrm{~mm}$ and approximately $10 \%$ of clods smaller than $10 \%$ (Figure 2a).
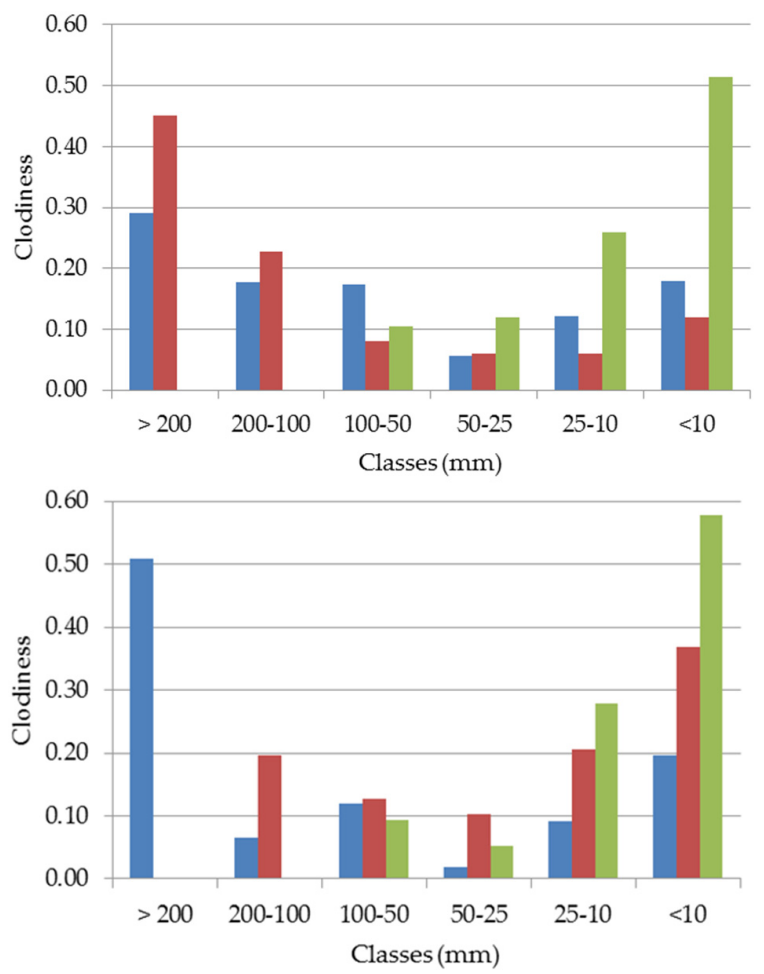

a

Figure 2. Clod size distribution of different treatments: (a) for LH (58\% FC) and (b) for HH ( $80 \%$ FC).

Regarding the water infiltration rate of the soil, the results depicted in Figure 3 showed that, due to the hard field conditions of the silty loam soil, only the 3 following treatments had results: P40 LH and P20 LH (2 replications), P20 HH (1 replication). In particular, the highest values of the infiltration rate (above $2500 \mathrm{~mm} \cdot \mathrm{h}^{-1}$ ) was obtained for P20 LH, similar values (between 500 and 
$1000 \mathrm{~mm} \cdot \mathrm{h}^{-1}$ ) were obtained for the treatments P40 LH and P20 HH and finally, a value equal to 0 for the MT treatment were obtained.

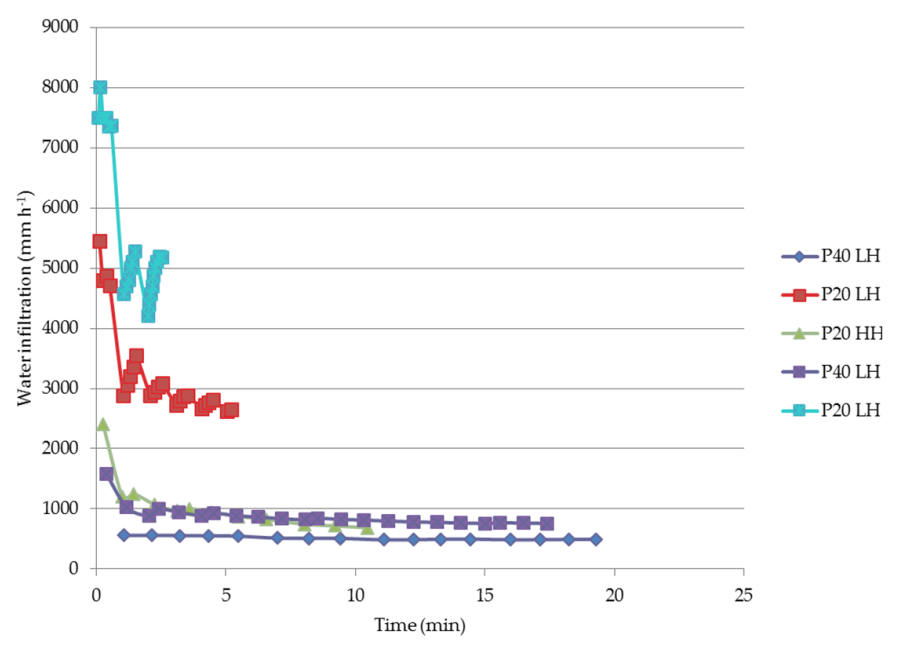

Figure 3. Soil water infiltration rate.

Findings of structural stability of soil aggregates showed that treatment $\mathrm{P} 40$ had the highest structural stability value within the LH treatments (68.7\%). Treatments P20 and MT showed quite similar values, $66 \%$ and $65.3 \%$, respectively (Figure $4 \mathrm{a}$ ). Results of tests conducted on $\mathrm{HH}$ treatments showed that the best effect on structural stability was created by the MT treatment $(70 \%)$, while ploughed plots showed values of $65.3 \%$ and $64 \%$ for P20 and P40, respectively (Figure $4 \mathrm{~b}$ ).
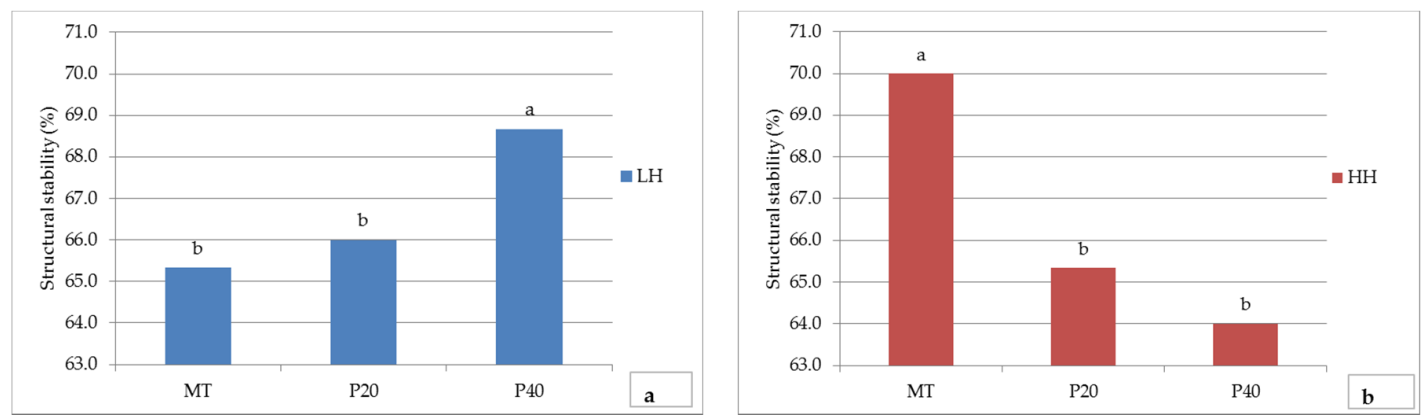

Figure 4. Structural stability of soil aggregates related: (a) to low water content treatments LH (58\% FC) and (b) to high water content treatments $\mathrm{HH}(80 \% \mathrm{FC})$. Average of 18 values.

According to the structural stability of soil aggregates, the results of wheat yield (Figure 5) showed that grain yield under the LH condition was higher for the P40 treatment $\left(2.1 \mathrm{t} \cdot \mathrm{ha}^{-1}\right)$ and for P20 $\left(2.05 \mathrm{t} \cdot \mathrm{ha}^{-1}\right)$, it was lower for MT $\left(1.7 \mathrm{t} \cdot \mathrm{ha}^{-1}\right)$. The trend of grain yield under HH was similar to that of the LH condition: higher for P40 (1.9 t.ha $\left.{ }^{-1}\right)$ and for P20 (1.5 t.ha $\left.{ }^{-1}\right)$, lower for MT (1.3 tha $\left.{ }^{-1}\right)$. Figure 5 shows the values of differences in grain yield with respect to the treatment P40 (treatment P40 was chosen as the control because it represents the traditional tillage of this crop). Concerning condition LH, P20 and P40 produced the same amount while MT produced 23\% less; regarding the $\mathrm{HH}$ condition, P20 and MT produced $26 \%$ and $46 \%$ less, respectively, than P40. The grain yield of each treatment in LH was higher than the respective treatment $\mathrm{HH}$ : treatments P40 and P20 produced the highest, MT the lowest. 


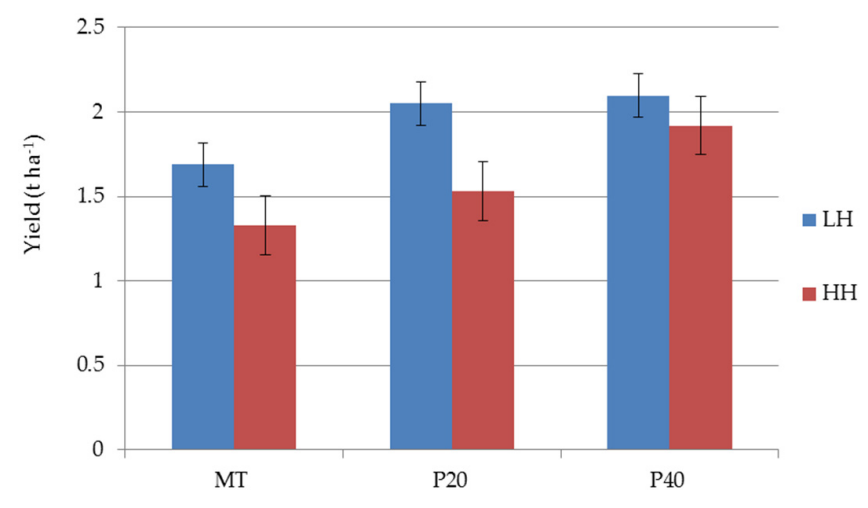

Figure 5. Results of wheat harvesting (Error bars represent the standard deviation. Average of 18 values).

Highly significant linear relationships between soil penetration resistance and yield for three treatments at each soil water content (Figure 6) were found.

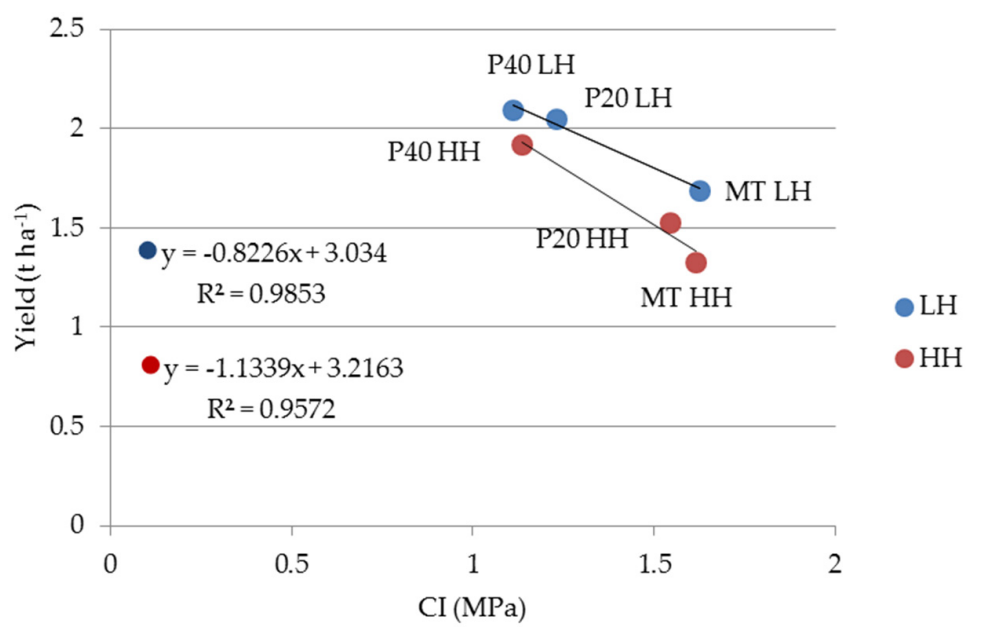

Figure 6. Relationships between grain yield and soil penetration resistance for low (LH) and high (HH) soil water content $(p \leq 0.01)$.

\section{Discussion}

In view of recent international agreements, which set an ambitious goal of limiting the increase in global temperature by $1.5^{\circ} \mathrm{C}$, the actions that each country will undertake will be crucial for the success of such an agreement, and it will be necessary to intervene in the most energy-intensive sectors and/or polluting human activities. In global terms, agro-food industries, both agriculture and livestock, are sources of $\mathrm{CO}_{2}$ emissions. In the Italian context, the regional development plans have established funds aimed at innovation and the energy efficiency of farms, offering the possibility to achieve greater environmental sustainability.

According to [4], tillage is a fundamental factor influencing soil quality. In Central Italy, mouldboard deep ploughing is widely used but it has several disadvantages compared with shallower tillage [16], such as greater energy requirement as shown in Tables 4 and 5, surface roughness as shown in Figure 2, and often, the degree of crushing of the soil requires further operation for seedbed preparation.

The results obtained in this research showed that the soil water content significantly influenced the soil strength in terms of penetration resistance and shear strength and consequently, the tractor performance during ploughing. In fact, in low water content plots, the area-specific consumption, the 
global energy employed, fossil-fuel energy requirements and $\mathrm{CO}_{2}$ emissions were significantly higher during ploughing at $0.40 \mathrm{~m}$ and $0.20 \mathrm{~m}$ depth compared to the high water content plots. Better tractor performance during ploughing at $0.20 \mathrm{~m}$ with high water content and during harrowing was found. Regarding soil quality, treatments P20 LH and P40 LH showed good effects on structural stability and grain yield. Furthermore, the soil structure created by treatment P20 LH allowed an optimal water infiltration rate, meaning that runoff was reduced and a high percentage of rainwater was stored [23]. It is suggested that trafficking and tillage only be conducted when the soil moisture is less than $60 \%$ of field capacity. The presence of vehicle traffic when soil moisture is greater than approximately $60 \%$ of field capacity can lead to excessive soil compaction that may be a problem for many cropping seasons or worse, the damage may be permanent. Results showed that under the field condition of the tests, according to other studies carried out by [10], tillage can be carried out at a water content up to 0.8 of field capacity, as the $\mathrm{P} 40 \mathrm{HH}$ treatment showed.

Besides, according to other studies [24], a highly significant linear relationship between grain yield and soil penetration resistance $(p \leq 0.01)$ was found, highlighting how soil physical-mechanical parameters may be good indicators of productivity. In fact, the results showed that under the field conditions of the tests, the crop yield decreases when the soil strength, in terms of the Cone Index, increases (Figure 6). Even if the best tillage operation is used, there is a compromise among targets: machines, meteorological conditions, yield, soil status, and costs. The obtained results showed that the MT and P20 treatments are suitable for these field conditions under climate change scenarios because MT was not affected by the soil water content, and P20 was a good compromise among targets.

\section{Conclusions}

In the present study, two georeferenced sampling tests of certain soil properties were carried out before and after tillage. Soil tillage was performed at low and high water content $(58 \%$ and $80 \%$ of field capacity, respectively). The performance of the tractors carrying out the tillage operations was evaluated.

We found that (i) the soil water content had a significant influence on soil strength and consequently, the tractor performance during ploughing. Tillage operation and soil water content are both highly correlated with soil strength. The values of penetration resistance and shear strength decreased significantly $(\Delta>50 \%)$ in the sampling tests carried out after tillage; (ii) During tillage, three field-oriented performance indicators were found: time efficiency, area-specific consumption and tractor slip. In the tests carried out at a water content of $58 \%$ of the field capacity, the three performance indicators were high during ploughing at the $0.40 \mathrm{~m}$ depth, while in the tests carried out at a water content of $80 \%$ of the field capacity, all these indicators were significantly lower. Between the two different field conditions (low and high water content), no differences were found in the performance of the tracked tractor during harrowing (MT treatment); (iii) Similar to the structural stability of the soil aggregates, wheat yield in the LH treatment was higher than the respective $\mathrm{HH}$ treatment. Under both LH and HH conditions, the P40 treatment had the highest yield, and MT the lowest. There was a significant linear correlation between soil penetration resistance and crop yield across the different treatments and soil conditions.

Acknowledgments: This work was carried out under the auspices of the special project "Sceneries of adaptation of the Italian agriculture to the climatic changes" (AGROSCENARI) D.M. 8608/7303/2008 of 7.8.2008 of the Consiglio per la ricerca e la sperimentazione in agricoltura (CREA), and Italian Ministry of the Agricultural and Forestry Politics. The authors wish to thank U. Neri, V. Giuliani and D. Dell'Unto for their help during field tests.

Author Contributions: Pieranna Servadio was responsible for management of the project, data collection, statistical analysis, interpretation of results, manuscript preparation and editing. Simone Bergonzoli was involved in data collection, manuscript preparation and editing. Claudio Beni was involved in data collection and manuscript preparation.

Conflicts of Interest: The authors declare no conflict of interest. 


\section{References}

1. Earl, R. Prediction of trafficability and workability from soil moisture deficit. Soil Tillage Res. 1997, 40, 155-168. [CrossRef]

2. Koch, H.J.; Heuer, H.; Tomanová, O.; Marlander, B. Cumulative effect of annually repeated passes of heavy agricultural machinery on soil structural properties and sugar beet yield under two tillage systems. Soil Tillage Res. 2008, 101, 69-77. [CrossRef]

3. Hamza, A.M.; Anderson, W.K. Soil compaction in cropping systems. A review of the nature, causes and possible solutions. Soil Tillage Res. 2005, 82, 121-145. [CrossRef]

4. Munkholm, L.J.; Heck, R.J.; Deen, B. Long-term rotation and tillage effects on soil structure and crop yield. Soil Tillage Res. 2012. [CrossRef]

5. Utset, A.; Cid, G. Soil penetrometer resistance spatial variability in a Ferrasol at several soil moisture conditions. Soil Tillage Res. 2001, 61, 193-202. [CrossRef]

6. Beni, C.; Servadio, P.; Marconi, S.; Neri, U.; Aromolo, R.; Diana, G. Anaerobic Digestate Administration: Effect on Soil Phisical and Mechanical. Comun. Soil Sci. Plant Anal. 2012, 43, 821-834. [CrossRef]

7. Servadio, P.; Bergonzoli, S. Spatial variability within a field and global efficiency during soil tillage. In Proceedings of the ISTVS 13th European Conference, Rome, Italy, 21-23 October 2015.

8. Becher, H.H. Resistances to penetration of aggregates from loess-drived topsoils at different soil water tensions. Soil Tillage Res. 1998, 47, 73-81. [CrossRef]

9. Servadio, P. Applications of empirical methods in central Italy for predicting field wheeled and tracked vehicle performance. Soil Tillage Res. 2010, 110, 236-242. [CrossRef]

10. Servadio, P. Compaction Effects of Green Vegetable Harvester Fitted with Different running gear systems and soil-machinery relationship. J. Agric. Sci. Appl. 2013, 2, 72-79.

11. Lyles, L.; Woodruff, N.P. How moisture and tillage affect cloddiness for wind erosion control. Agric. Eng. 1962, 42, 150-153.

12. Strudley, M.W.; Green, R.T.; Ascough, J.C., II. Tillage effects on soil hydraulic properties in space and time: State of the science. Soil Tillage Res. 2008, 99, 4-48. [CrossRef]

13. Servadio, P.; Bergonzoli, S. Performances of different type of tractors in forestry soil conservation tillage. In Proceedings of the NJF Seminar 448: Soil Compaction Effects on Soil Functions and Strategies for Prevention, Helsinki, Finland, 6-8 March 2012.

14. Servadio, P.; Bergonzoli, S. Tractors and machineries for conservative soil tillage in climate change conditions. In Proceedings of the International Conference on Agricultural Engineering (CIGR-AgEng), Valencia, Spain, 8-12 July 2012.

15. Hajabbasi, M.A.; Hemmat, A. Tillage impacts on aggregate stability and crop productivity in a clay-loam soil in central Iran. Soil Tillage Res. 2000, 56, 205-212. [CrossRef]

16. Servadio, P.; Bergonzoli, S.; Toderi, M. Soil mapping to assess workability in central Italy as climate change adaptation technique. Glob. Nest J. 2014, 16, 229-239.

17. Burgun, C.; Lacour, S.; Delacroix, A.; Descombes, G.; Doyen, V. Computing time and fuel requirements to assess efficiency of a field work from conventional laboratory tests: Application to a plowing operation. Agric. Food Sci. 2013, 22, 247-261.

18. Kemper, W.D. Aggregate stability. In Methods of Soil Analysis; Part 1; American Society of Agronomy, Soil Science Society of America: Madison, WI, USA, 1965; pp. 511-519.

19. Bouwer, H. Intake rate: Cylinder. In Methods of Soil Analysis; Klute, A., Ed.; ASA: Madison, WI, USA, 1986; pp. 825-843.

20. Bagarello, V.; Iovino, M.; Elrick, D.E. A simplified falling-head technique for rapid determination of field-saturated hydraulic conductivity. Soil Sci. Soc. Am. J. 2004, 68, 66-73. [CrossRef]

21. Barbour, M.G.; Burk, J.H.; Pitts, W.D.; Gilliam, F.S.; Schwartz, M.W. Terrestrial Plant Ecology; Benjamin Cummings: San Francisco, CA, USA, 1998; pp. 182-204.

22. Gomez, K.A.; Gomez, A.A. Statistical procedures for agricultural research with emphasis on rice. In Statistical Procedures for Agricultural Research with Emphasis on Rice; The International Rice Research Institute: Manila, Philippines, 1976. 
23. Raper, R.L. Agricultural traffic impacts on soil. J. Terramech. 2005, 42, 259-280. [CrossRef]

24. Marsili, A.; Servadio, P.; Pagliai, M.; Vignozzi, N. Compattamento del suolo causato dal traffico di trattrici equipaggiate con cingoli di differente tipo ed effetti sulla produzione vegetale. (Soil compaction due to the traffic of the tractors equipped with different type of tracks and effects on the yield). Riv. Ing. Agrar. 1998, 3, 144-149.

(C) (1)

(C) 2016 by the authors; licensee MDPI, Basel, Switzerland. This article is an open access article distributed under the terms and conditions of the Creative Commons Attribution (CC-BY) license (http://creativecommons.org/licenses/by/4.0/). 